\title{
Optimizing Tomato (Solanum lycopersicum L.) Growth With Different Combinations of Organo-Mineral Fertilizers
}

\section{Adama Traoré ${ }^{\dagger}$, Alimata Arzouma Bandaogo ${ }^{* \dagger}$, Ouango Maurice Savadogo ${ }^{\dagger}$, Fatimata Saba, Audrey Leiticia Ouédraogo, Yaya Sako, Idriss Sermé and Souleymane Ouédraogo}

Department of Natural Resources Management, Institute of Environment and Agricultural Research (INERA), Bobo-Dioulasso, Burkina Faso

With the aim of promoting sustainable agriculture that respects the environment and human health, a study was carried out to evaluate the impact of organic and mineral fertilizers on tomato plant cultivation. The study was carried out at the Research Station of Farako-Bâ in Burkina Faso. A complete randomized block of Fisher design with four replications was used to carry out the experiment. The treatments were as follows: TO: control (compost 15 t/ha); T1: compost (15 t/ha) + biosol (160 kg/ha) + urea (35 kg/ha) + NPK (87.5 kg/ha) + KCl (52.5 kg/ha); T2: compost (15 t/ha) + neem seed cake (10 $\mathrm{t} / \mathrm{ha})+$ urea $(100 \mathrm{~kg} / \mathrm{ha})+\mathrm{NPK}(250 \mathrm{~kg} / \mathrm{ha})+\mathrm{KCl}(150 \mathrm{~kg} / \mathrm{ha}) ;$ T3: compost (15 t/ha) + biochar $(10 \mathrm{t} / \mathrm{ha})+$ urea $(100 \mathrm{~kg} / \mathrm{ha})+\mathrm{NPK}(250 \mathrm{~kg} / \mathrm{ha})+\mathrm{KCl}(150 \mathrm{~kg} / \mathrm{ha})$. The data collected were collar diameter, height of plants, number of fruits, fruit diameter, and tomato fruit yield. The results showed that the combination organo-mineral fertilizers had a significant effect on tomato plant productivity. Application of neem seed cake and mineral fertilizers was the most efficient treatment with a yield increase of 53\% and $40 \%$ in 2019, respectively. In 2020, the yield increase was 32 and 85\% for biochar and biosol, respectively. Incorporation of organo-mineral fertilizers has improved soil organic and nutrient status, which ultimately promotes crop growth of tomato plant. Neem cake can be effectively used to increase tomato plant productivity and farmer's income and also maintain soil fertility.

Keywords: organic amendment, mineral fertilizer, tomato productivity, yield, growth

\section{INTRODUCTION}

Agriculture remains a vital sector for sub-Saharan African countries. Burkina Faso's economy is based on agriculture, which employs more than $80 \%$ of the population and contributes about $31 \%$ to the gross domestic product (PNDES, 2016). Among the agricultural sectors, vegetable farming occupies a prominent place (MAHRH, 2011). The sector is an important source of foreign exchange for the national economy (CILSS, 2017). Tomato cultivation takes second place after onion in terms of cultivated area and volume of production. In 2018, tomato production has reached 167,400 tons, about $0.8 \%$ of African production, and generated more than 78 billion FCFA in Burkina Faso (MAAHA, 2019). However, the yield of tomatoes declined from 12.5 tons (t)/ha in 2012 to 10.9 $\mathrm{t} /$ ha in 2018 (Faostat, 2020). This decline in yield is linked to sub-optimal crop management, which 
could include poor fertilization and irrigation, and to abiotic constraints (pedoclimatic variations, land degradation, etc.) (Ferrante and Mariani, 2018; Ullah et al., 2021). The fundamental cause is the degradation of land followed by their loss of fertility (physical, chemical, and biological fertility). In Burkina Faso, land degradation now affects $24 \%$ of arable land and threatens to undermine medium- and long-term food security. Tomato is grown by using conventional as well as organic fertilizers. The use of organic manure has been reported to improve biological, chemical, and physical properties of the soil and invariably increase plant growth and yield because of its high organic matter content due to high microbial activity (Mitran et al., 2017). Organic amendments such as such biochar, compost, and neem seed cake are compounds rich in organic matter that can be used for tomato production. Biochar is widely used in soil amendment for improving physicochemical properties and biological activities of agricultural soils. Biochars can be used as soil amendments for improving soil properties and crop yield, and secondly, storing biochars in soils is regarded as a means for permanently sequestering carbon (Glaser et al., 2002; Lehmann et al., 2006). Neem seed cake is rich in plant nutrients (crude protein 13-18\%; carbohydrate 24-50\%; crude fiber $8-26 \%$; fat $2-13 \%$; ash $5-18 \%$; and acid-insoluble ash $1-$ $17 \%$, with nitrogen, phosphorus, calcium, and magnesium) and is used as manure for soil amendment and for urea coating (Puri, 1999). However, fertilizer sources can have a significant effect on tomato quality (Toor et al., 2006). Extensive use of inorganic fertilizer has a depressing effect on yield, by causing a reduction in number of fruits, and delays and reduces fruit setting, which consequently delays ripening and leads to heavy vegetative growth (Aliyu et al., 2003). Many other authors (Ayeni and Ezeh, 2017; Islam et al., 2017; Wu et al., 2020) mentioned the positive effect of the combination of organo-mineral fertilizers on tomato productivity. Also, the beneficial effect of combined organic manure with bio-fertilizer on availability of nutrients was reported by Fernandes and Bhalerao (2015) and Youssef and Eissa (2017). The objective of this study is to propose alternative solutions for maintaining or improving soil fertility and increasing tomato productivity by combining different sources of organic amendments and inorganic fertilizers.

\section{MATERIALS AND METHODS}

\section{Experimental Site}

The experiment was conducted in 2019 and 2020 in FarakoBâ Research Station ( $4^{\circ} 20 \mathrm{~W}$ Longitude, $11^{\circ} 06 \mathrm{~N}$ Latitude, $405 \mathrm{~m}$ above sea level). The climate is south-Sudanese type, with a rainy season ranging between May and October, and a dry season, from November to April. The annual average rainfall in the area is between 900 and $1,100 \mathrm{~mm}$. The temperature varies between 17 and $37^{\circ} \mathrm{C}$ during the dry season and during the rainy season between 10 and $32^{\circ} \mathrm{C}$. During the experiment period from 2019 to 2020 , the mean annual rainfall was between 1,248 and $1,282 \mathrm{~mm}$, received on 73 to 63 days, respectively. The rainfall distribution was characterized by frequent dry spells. The experiment was implemented on a tropical ferruginous soil (lixisol).

\section{Soil Sampling}

Diagonal soil sampling method was used to collect soil samples in each elementary plot in five points and soil composite sample was made per treatment for soil analysis before and after the experimentation. Soil samples were taken on 0$10 \mathrm{~cm}, 10-20 \mathrm{~cm}$, and $20-30 \mathrm{~cm}$ depth in 2019 to determine soil chemical properties. Cation-exchange capacities (CEC) were determined, as well as total $\mathrm{N}$, total $\mathrm{P}$, total $\mathrm{K}$, available $\mathrm{P}$, available $\mathrm{K}$, soil organic matter (OM), organic carbon $(\mathrm{OC})$, and $\mathrm{pH}$. Soil $\mathrm{pH}$ was measured using an electronic $\mathrm{pH}$ meter according to the international standard ISO 10390, carbon according to Walkley and Black (1934), total nitrogen and total phosphorus by mineralization according to the Kjeldahl method, and available phosphorus according to Bray 1 method (Bray and Kurtz, 1945), and available potassium was determined with a flame photometer. The Metson method (Metson, 1956) was used to determine the CEC. Calcium (Ca) of organic amendments was analyzed with the flame photometer method, and other parameters were analyzed by using the same method for soil analysis.

\section{Plant Material}

Hybrid tomato varieties Lindo F1 and Mongal F1 with a cycle of 65 days were used on January to March in 2019 and on May to September in 2020, respectively. The fruit weight of Lindo F1 and Mongal F1 are $90 \mathrm{~g}$ and 100-120 g, respectively. These varieties were chosen according to their adaptability to all the season and market demand.

\section{Organic Amendments}

Compost was obtained by the process of composting in pile of sorghum straw and cow dung during 3 months. For the composting, an area of $2 \times 1.5 \mathrm{~m}$ was delimited to build a pile. The surface was filled with straw $(30 \mathrm{~cm}$ of height) and cow dung ( $5 \mathrm{~cm}$ of height), and $1 \mathrm{~cm}$ of ash was added to complete one layer. Tree layer of the mixture was done to build one pile. Biochar was obtained by the pyrolyzing of cotton biomass, and neem seed cake was obtained after neem oil processing and biosol (bio-organic fertilizer) were used for the experiment. Their characteristics are presented in Table 1. Neem seed cake and biosol are compounds rich in organic matter, total nitrogen, total $\mathrm{K}, \mathrm{Ca}$, and acidic $\mathrm{pH}$ compared to compost and biochar, which are alkaline ( 9.09 to $10.16 \mathrm{pH}$ value).

\section{Mineral Fertilizers}

Mineral fertilization of tomatoes was ensured by single urea [CO $\left(\mathrm{NH}_{2}\right)_{2}$ ] with $46 \%$ nitrogen content, potassium chloride with $60 \% \mathrm{~K}_{2} \mathrm{O}$ content, and NPK (14-23-14).

\section{Experimental Design}

This study was carried out in a complete randomized Fisher block design, with four treatments and four replications. Plants of 1 month in nursery were transplanted to their respective treatment plots at a spacing of $80 \times 40 \mathrm{~cm}$. A surface of $2.4 \mathrm{~m}^{2}$ was assigned to each treatment. The treatments consisted of T0 (Control): compost (15 t/ha); T1: compost (15 t/ha) + biosol (160 kg/ha) + urea $(35 \mathrm{~kg} / \mathrm{ha})+\mathrm{NPK}(87.5 \mathrm{~kg} / \mathrm{ha})+\mathrm{KCl}(52.5 \mathrm{~kg} / \mathrm{ha}) ; \mathrm{T} 2$ : 
TABLE 1 | Characteristic of organic amendments.

\begin{tabular}{|c|c|c|c|c|c|c|c|}
\hline Organic amendments & $\mathrm{pHw}$ & OM (\%) & N (\%) & $\mathrm{C} / \mathrm{N}$ & Total P (mg/kg) & Total K (mg/kg) & Total Ca (mg/kg) \\
\hline Compost & 9.09 & 41.06 & 1.20 & 19.90 & $1,528.43$ & $13,667.24$ & $21,631.99$ \\
\hline Biochar & 10.16 & 72.64 & 0.88 & 47.96 & $3,441.46$ & $17,151.93$ & $29,192.73$ \\
\hline Neem seed cake & 5.81 & 82.28 & 6.32 & 7.55 & $3,098.17$ & $30,521.58$ & $36,919.91$ \\
\hline Biosol & 7.00 & 77.23 & 15.30 & 2.93 & $1,118.15$ & $40,490.82$ & $76,217.47$ \\
\hline
\end{tabular}

compost $(15 \mathrm{t} / \mathrm{ha})+$ neem seed cake $(10 \mathrm{t} / \mathrm{ha})+$ urea $(100 \mathrm{~kg} / \mathrm{ha})$ + NPK (250 kg/ha) + KCl (150 kg/ha); and T3: compost (15 t/ha) + biochar $(10 \mathrm{t} / \mathrm{ha})+$ urea $(100 \mathrm{~kg} / \mathrm{ha})+\mathrm{NPK}(250 \mathrm{~kg} / \mathrm{ha})+$ $\mathrm{KCl}(150 \mathrm{~kg} / \mathrm{ha})$. Fertilizer application was done according to the recommendation. Urea was applied at transplanting (50\%) and at the flowering stage (50\%), and the other mineral fertilizers were applied at transplanting (15 days after transplanting). Organic manure (compost) was applied at the rate of $5 \mathrm{t} / \mathrm{ha}$ during land preparation by broadcasting, and the other organic manures were locally applied 5 days after transplanting near the plant. Tomato protection was ensured by usual insecticides chlorpyriphos-ethyl $480 \mathrm{~g} / \mathrm{L}$ and active Acetamiprid $16 \mathrm{~g} / \mathrm{L}+$ indoxacarb $30 \mathrm{~g} / \mathrm{L}$. Irrigation was done when needed. The agronomic parameters were determined as follows: Plant height was determined by measuring the tomato stand from the base to the tip, plant diameter was determined by measuring the tomato stem from the base, the number of fruits were counted per treatment, and the fruits were hand-picked weekly and weighed.

\section{Data Analysis}

After verifying the normality of the data by Shapiro-Wilk test, the means of different treatments were subjected to Fisher's analysis of variance (ANOVA), with XL STAT 2016. Means were separated using LSD at 5\% probability level.

\section{RESULTS}

\section{Soil Characteristics With Organo-Mineral Fertilizers}

The incorporation of soil organic amendments showed significant improvement on soil parameters (Table 2). In soil depth $0-10 \mathrm{~cm}$, the addition of soil amendments led to enhance soil organic carbon contents and organic matter. The significant improvement in soil carbon was recorded by 64.1, 42.8, and $35.92 \%$, when compost and neem cake, compost and biosol, and compost only were incorporated, respectively, over the initial soil. Similarly, total nitrogen improved with the association of organo-mineral fertilizers and the highest value $(0.09 \%)$ was obtained with the treatment $\mathrm{T} 1$ [compost $(15 \mathrm{t} / \mathrm{ha})+$ biosol $(160 \mathrm{~kg} / \mathrm{ha})+$ urea $(35 \mathrm{~kg} / \mathrm{ha})+\mathrm{NPK}(87.5 \mathrm{~kg} / \mathrm{ha})+\mathrm{KCl}(52.5$ $\mathrm{kg} / \mathrm{ha})$ ]. Likewise, the application of both organic and mineral fertilizers significantly increased soil total $\mathrm{P}$, total $\mathrm{K}$, available $\mathrm{P}$, available $\mathrm{K}$, and CEC by $67.55,45.03,248.48,13.63$, and $30.61 \%$, with the treatment T2 [(compost $(15 \mathrm{t} / \mathrm{ha})+$ neem seed cake $(10$ $\mathrm{t} / \mathrm{ha})+$ urea $(100 \mathrm{~kg} / \mathrm{ha})+\mathrm{NPK}(250 \mathrm{~kg} / \mathrm{ha})+\mathrm{KCl}(150 \mathrm{~kg} / \mathrm{ha})]$ respectively, over initial soil.
Soil $\mathrm{pH}$ increases with the use of organic amendments and mineral fertilizers in both depths, generally. The increase was 6.09 and $12.42 \%$ in soil depths $0-10$ and $10-20 \mathrm{~cm}$ with the treatment T0 [compost ( $\mathrm{t} / \mathrm{ha})]$ respectively, over initial soil.

The use of biochar, compost, and mineral fertilizers (T3) efficiently $(p<0.05)$ increased soil organic matter, organic carbon, total N, available $\mathrm{P}$, available $\mathrm{K}$, and CEC in soil depth 10$20 \mathrm{~cm}$ by $65.38,66.67,71.43,116,11.64$, and $29.89 \%$ respectively, over the initial soil.

\section{Plant Growth With Organo-Mineral Fertilizers}

Plant diameter was significantly $(p<0.01)$ higher with T3 [compost $(15 \mathrm{t} / \mathrm{ha})+$ biochar $(10 \mathrm{t} / \mathrm{ha})+$ urea $(100 \mathrm{~kg} / \mathrm{ha})+$ NPK (250 kg/ha) + KCl (150 kg/ha)] 30 days after transplanting and lower plant diameter was obtained with T0 (compost only) in 2019 (Figure 1). At the end of the experiment, maximum plant diameter with T3 $(1.11 \mathrm{~cm})$ was $7 \%$ and $10 \%$ higher than T2 and T1, respectively. In 2020, higher plant diameter was observed with treatment T2 [compost $(15 \mathrm{t} / \mathrm{ha})+$ neem seed cake $(10 \mathrm{t} / \mathrm{ha})+$ urea $(100 \mathrm{~kg} / \mathrm{ha})+\mathrm{NPK}(250 \mathrm{~kg} / \mathrm{ha})+\mathrm{KCl}$ (150 kg/ha)] and lower plant diameter was obtained with T0 (compost) during all the experiment time. Similarly, 27, 26, and $11 \%$ plant diameter increases were recorded with T2, T3, and T1 applications compared to T0 $(0.80 \mathrm{~cm})$. Significant difference was observed with plant height only in the later stage of growth between all the treatments in 2019 and higher plant height was recorded with $\mathrm{T} 3(53.33 \mathrm{~cm})$. In 2020, all the treatments were significantly different in all stages. In general, lower plant growth rate was observed with $\mathrm{T} 0(55.17 \mathrm{~cm})$ and higher growth rate was obtained with T2 $(66.92 \mathrm{~cm})$ (Figure 2).

\section{Yield Component and Yield of Tomato Plant With Organo-Mineral Fertilizers}

The number of tomato fruits and fruit diameter were significantly $(p<0.001)$ increased with the different combinations of organomineral fertilizers in 2020 (Table 3). The highest number of fruit per plant was obtained with T2 (15.39), and the increase over T3, $\mathrm{T} 1$, and $\mathrm{T} 0$ was 29,77 , and $171 \%$, respectively. Fruit diameter was higher with T2 $(6.16 \mathrm{~cm})$ and lower fruit diameter was obtained with T0 $(5.10 \mathrm{~cm})$. Data presented in Table 4 show a significant difference $(p<0.001)$ between treatment and fruit yield, and the highest yield in 2019 and 2020 was recorded with treatment T2 (19.17 and $49.82 \mathrm{t} / \mathrm{ha}$, respectively). T2, T3, and T1 increased fruit yield of tomato by about 91,53 , and $41 \%$ compared to T0 (10.04 t/ha) in 2019. Similarly, 351, 84, and 32\% fruit yield increases 
TABLE 2 | Soil chemical characteristics at different depths.

\begin{tabular}{|c|c|c|c|c|c|c|c|c|c|c|}
\hline Treatment & pHw & OM (\%) & OC (\%) & Total $N(\%)$ & $\mathrm{C} / \mathrm{N}$ & Total P (mg/kg) & Av-P (mg/kg) & Total K (mg/kg) & Av-K (mg/kg) & CEC (cmol/kg) \\
\hline \multicolumn{11}{|c|}{ Depth 0-10 cm } \\
\hline IS & $6.40 b$ & $1.03 c$ & $0.60 b$ & $0.053 c$ & $11.31 \mathrm{a}$ & $109.7 c$ & $5.92 \mathrm{e}$ & $1,375.4 \mathrm{e}$ & $84.4 b$ & $3.43 b$ \\
\hline TO & $6.79 a$ & $1.40 \mathrm{~b}$ & $0.81 \mathrm{ab}$ & $0.083 b$ & $9.79 a$ & $160.5 b$ & $15.33 c$ & $1,613.0 d$ & $63.1 \mathrm{c}$ & $5.08 a$ \\
\hline $\mathrm{T} 1$ & $6.66 a$ & $1.47 \mathrm{~b}$ & $0.86 a$ & $0.090 \mathrm{a}$ & $9.50 \mathrm{a}$ & $156.7 b$ & $11.06 \mathrm{~d}$ & $1,805.8 \mathrm{c}$ & $56.8 \mathrm{c}$ & $4.29 a b$ \\
\hline $\mathrm{T} 2$ & $6.48 b$ & $1.69 a$ & $0.98 a$ & $0.090 a$ & $10.88 a$ & $183.8 \mathrm{a}$ & $20.63 a$ & $1,994.7 a$ & $95.9 a$ & $4.58 a$ \\
\hline Т3 & $6.76 a$ & $1.43 b$ & $0.83 a b$ & 0.080b & $10.36 \mathrm{a}$ & $162.4 b$ & $16.94 b$ & $1,859.3 b$ & $88.3 b$ & $4.63 a$ \\
\hline \multicolumn{11}{|c|}{ Depth $10-20 \mathrm{~cm}$} \\
\hline IS & $6.20 \mathrm{~b}$ & $0.78 b c$ & $0.45 b c$ & $0.042 \mathrm{c}$ & $10.96 a$ & $94.1 b$ & $2.86 d$ & $1,424 c$ & $82.5 b$ & $3.78 \mathrm{c}$ \\
\hline TO & $6.97 a$ & $1.06 b$ & $0.62 b$ & $0.058 \mathrm{~b}$ & $10.58 a$ & $106.4 \mathrm{a}$ & $4.40 c$ & $1,907 a$ & $45.4 \mathrm{C}$ & $5.38 a$ \\
\hline $\mathrm{T} 1$ & $6.67 a$ & $0.97 b$ & $0.56 b$ & $0.058 \mathrm{~b}$ & $9.89 a$ & $106.4 a$ & $4.47 \mathrm{c}$ & $1,705 b$ & $44.2 \mathrm{c}$ & $5.21 \mathrm{a}$ \\
\hline $\mathrm{T} 2$ & $6.68 \mathrm{a}$ & $1.03 b$ & $0.60 b$ & 0.060b & $9.94 a$ & $94.2 b$ & $5.64 b$ & 1,907a & $75.7 b$ & 4.69ab \\
\hline T3 & $6.68 a$ & $1.29 a$ & $0.75 a$ & $0.072 a$ & $10.37 a$ & $109.3 a$ & $6.88 a$ & $1,657 b$ & $92.1 \mathrm{a}$ & $4.91 \mathrm{a}$ \\
\hline
\end{tabular}

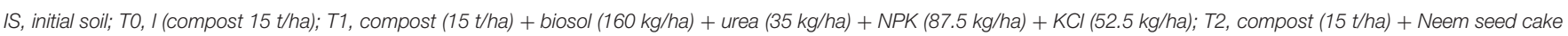



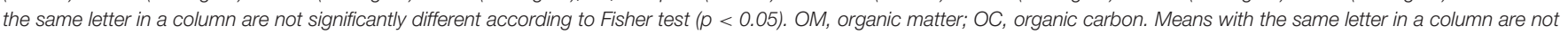
significantly different according to Fisher test $(p<0.05)$.

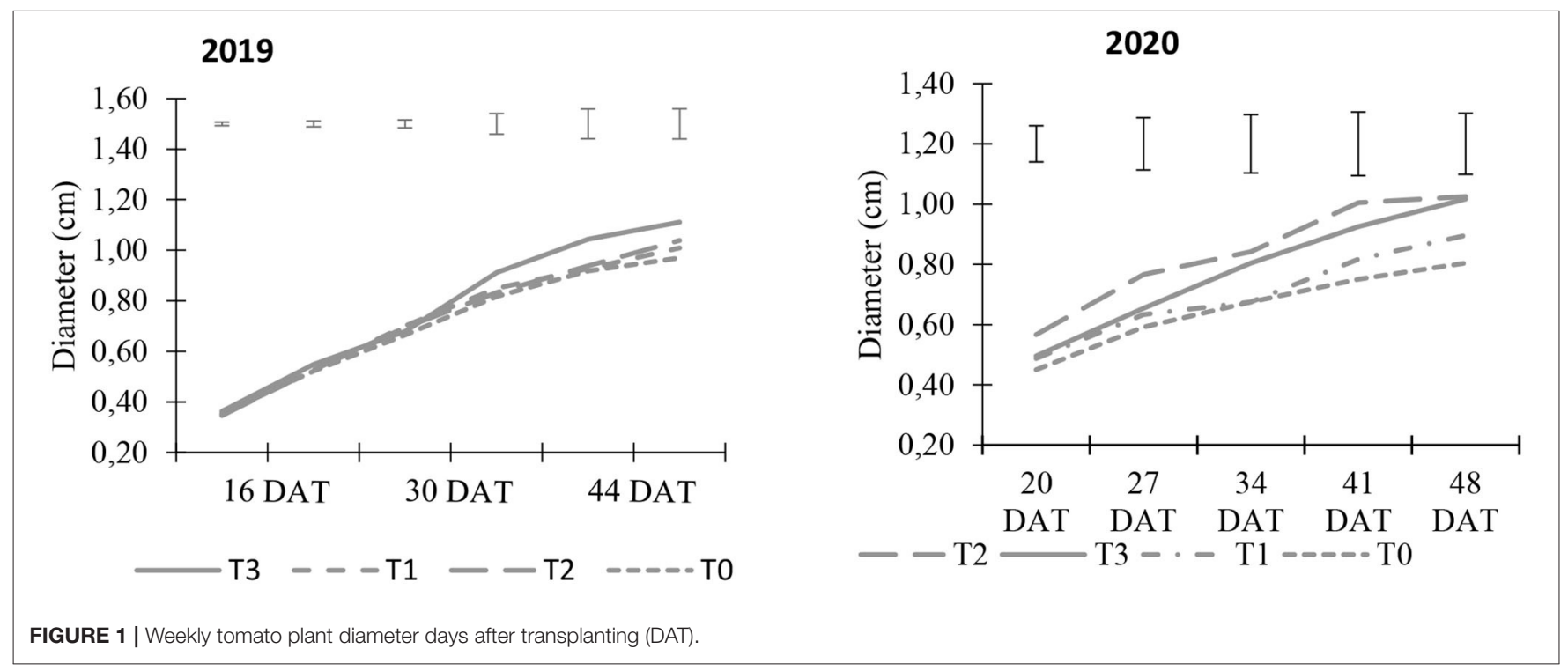

were observed with T2, T3, and T1 compared to T0 (11.05 t/ha) in 2020 .

\section{DISCUSSION}

The use organo-mineral fertilizers is required to supplement readily available nutrients and good growing environment (biological, chemical, and physical condition) for plant growth. Incorporation of organic amendments, especially addition of compost and neem cake or biochar, has efficiently increased soil organic status and soil nutrient level. The improvement of soil chemical properties and organic status is probably linked to the quality of the organic amendments that have been used for the study (Table 1). These results indicate that organic amendments are compounds rich in carbon and organic resources that provide an energy source for soil microorganisms that drive the various soil biological processes that enhance nutrient transformation and other quality parameters of soil (Fairhurst, 2012). The long-term use of organic amendments increases soil fertility by improving the structural and hydrological properties of soil and increasing soil organic matter and other macronutrients (Ramzan et al., 2021). According to Mulugeta and Getahun (2020), organic amendments play a positive role in chemical characteristics of the soil including increase in organic carbon (up to $58 \%$ with 120 t/ha vs. unfertilized soil) and organic nitrogen up to $90 \%$ depending on the type and the level applied. From the results, after 2 years of trials, soil fertility has increased with the combination of inorganic fertilizer and neem cake $(30.61 \%$ carbon and $64.1 \%$ CEC), or biochar (42.8\% CEC) and compost over the control. The finding of Ayamba et al. (2021), Bashir et al. (2021), Bergstrand et al. (2020), and Gorovtsov et al. 

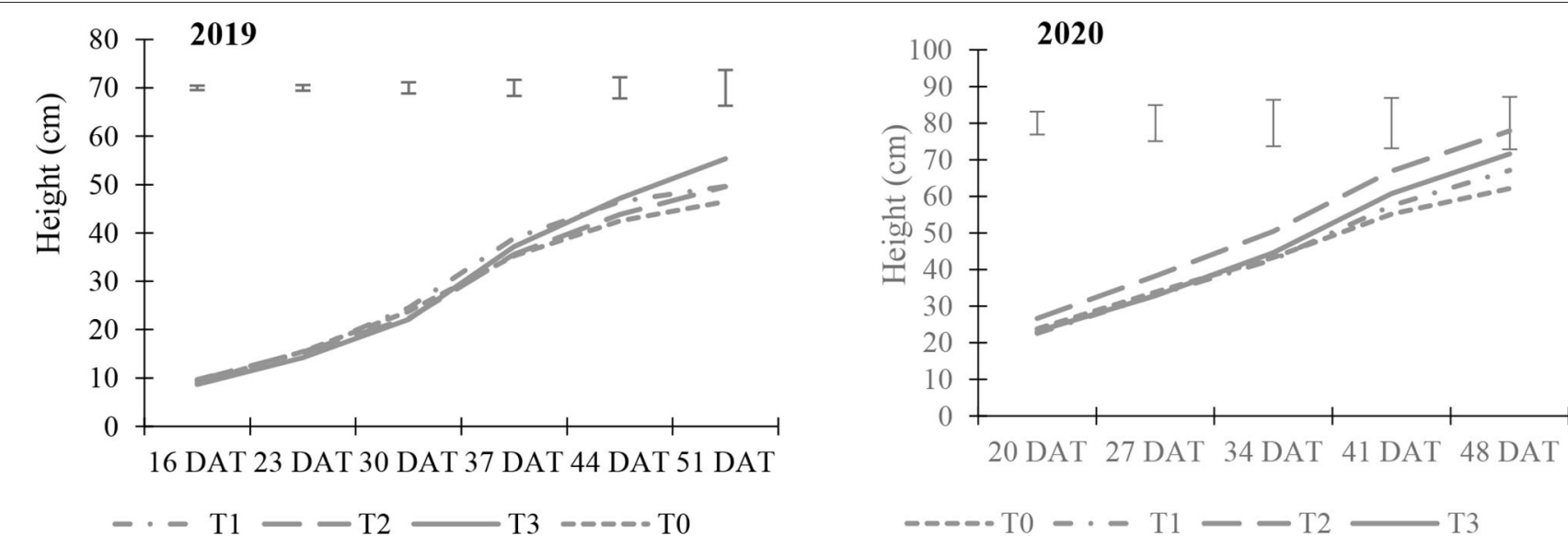

FIGURE 2 | Weekly tomato plant height days after transplanting (DAT).

TABLE 3 | Number of fruits and fruit diameter with organic and organo-mineral fertilizer application.

\begin{tabular}{lcc}
\hline Treatments & Number of fruits & Fruit diameter $\mathbf{( c m )}$ \\
\hline T0 & $5.66 \mathrm{~b}$ & $5.10 \mathrm{~d}$ \\
T1 & $8.66 \mathrm{~b}$ & $5.36 \mathrm{c}$ \\
T2 & $15.39 \mathrm{a}$ & $6.16 \mathrm{a}$ \\
T3 & $12.43 \mathrm{a}$ & $5.88 \mathrm{~b}$ \\
\hline
\end{tabular}

TO, I (compost 15 t/ha); T1, compost (15 t/ha) + biosol (160 kg/ha) + urea (35 kg/ha) + NPK (87.5 kg/ha) + KCl (52.5 kg/ha); T2, compost (15 t/ha) + Neem seed cake (10 t/ha) + urea (100 kg/ha) + NPK (250 kg/ha) + KCl (150 kg/ha); T3, compost (15 t/ha) + biochar (10 t/ha) + urea $(100 \mathrm{~kg} / \mathrm{ha})+\mathrm{NPK}(250 \mathrm{~kg} / \mathrm{ha})+\mathrm{KCl}(150 \mathrm{~kg} / \mathrm{ha})$. Means with the same letter in a column are not significantly different according to Fisher test (p $<0.05)$.

TABLE 4 | Tomato yield with organic and organo-mineral fertilizer application.

\begin{tabular}{lcc}
\hline Treatments & \multicolumn{2}{c}{ Tomato yield (t/ha) } \\
\cline { 2 - 3 } & $\mathbf{2 0 1 9}$ & $\mathbf{2 0 2 0}$ \\
\hline T0 & $10.04 \mathrm{c}$ & $11.05 \mathrm{~d}$ \\
T1 & $13.63 \mathrm{~b}$ & $26.98 \mathrm{c}$ \\
T2 & $19.17 \mathrm{a}$ & $49.82 \mathrm{a}$ \\
T3 & $12.55 \mathrm{~b}$ & $37.87 \mathrm{~b}$ \\
\hline
\end{tabular}

TO, I (compost 15 t/ha); T1, compost (15 t/ha) + biosol (160 kg/ha) + urea (35 kg/ha) + NPK (87.5 kg/ha) + KCl (52.5 kg/ha); T2, compost (15 t/ha) + Neem seed cake (10 t/ha) + urea (100 kg/ha) + NPK (250 kg/ha) + KCl (150 kg/ha); T3, compost (15 t/ha) + biochar (10 t/ha) + urea (100 kg/ha) + NPK (250 kg/ha) + KCl (150 kg/ha). Means with the same letter in a column are not significantly different according to Fisher test ( $p$ $<0.05)$.

(2019) showed that organic manure and their combination with mineral fertilizers can be efficient to improve soil fertility and crop productivity.

Application of organo-mineral fertilizers increased the height and diameter of the tomato plant in this experiment. In general, the highest values were obtained with the association of compost and biochar with mineral fertilizers in 2019 and lower plant diameter was obtained with the application of compost only.
This result can be attributed to the fact that biochar can increase soil cation exchange capacity and soil nutrient availability. High nutrient content and nutrient retention capacity lead to improved nutrient supply for plants and reduced nutrient losses by leaching (Glaser et al., 2002). Additionally, applying biochar to acidic soil improve soil $\mathrm{pH}$ and nutrient availability such as nitrogen and phosphorus (Van Zwieten et al., 2009; Blanco-Canqui, 2017; Fidel et al., 2018). These nutrients play an important role in plant growth by stimulating photosynthesis and biomass production. According to Hamer et al. (2004), biochar from maize residues in soils can promote mineralization of carbon compounds by enhancing the growth and dynamics (metabolism) of microorganisms. The finding of Nguyen et al. (2017) on short-term effects of organo-mineral biochar showed the positive effect of this combination over inorganic and organic fertilizer application separately. Also, Mustafa et al. (2010) showed that the application of biochar and mineral fertilizers increased plant height compared to the application of biochar or fertilizer alone. In 2020, growth parameters were positively influenced by mineral fertilizers and neem seed cake. Plant diameter and plant height increased about 27 and 21\%, respectively, compared to the application of compost only. Similarly, application of neem seed cake with inorganic fertilizer improved the number of fruits by $171 \%$ and fruit diameter by $21 \%$ compared to application of compost only. The highest fruit yield of tomato in the current work was also recorded from the combined application of neem seed cake + compost with inorganic fertilizers in both years (91 to 35\%). These results affirmed the finding of Wu et al. (2020) and Ayeni and Ezeh (2017) that the combination of organic and inorganic fertilizers has a positive effect on tomato productivity. The combination not only improves the organic status of soil but also increases inorganic fertilizer use efficiency. Also, neem seed cake amendment provides nutritional requirements, suppresses plant pest populations, and increases the yield and quality of agricultural crops. Koul and Shankar (1995) demonstrated that the major agricultural pests are sensitive to neem. The neem seed cake is also demonstrated to be rich in plant nutrients and is a 
good manure for soil amendment (Puri, 1999). The results are in conformity with the finding of Oyinlola et al. (2017) who find an improvement of soil properties and tomato yield with the used of neem seed cake. Each organic amendment has a specific importance on the improvement of soil characteristics. However, farmers need fertilizers that have a high impact in the short term. Soil improvement must also be followed in the long term to sustain soil productivity.

\section{CONCLUSION}

Tomato cultivation required important demand of nutrient supply. Organo-mineral fertilizers are a combined source of nutrient that can be effectively used to increase the long-term productivity of tomato plant. This study clearly showed that the

\section{REFERENCES}

Aliyu, L., Karikari, S. K., and Ahmed, M. K. (2003). Yield and yield components of eggplant (Solanium nigro L.) as affected by date of transplanting, intra row spacing and nitrogen fertilization. J. Agricult. Sci. Technol. 2, 7-12.

Ayamba, B. E., Abaidoo, R. C., Opoku, A., and Ewusi-Mensah, N. (2021). Enhancing the fertilizer value of cattle manure using organic resources for soil fertility improvement: a review. J. Bioresour. Manag. 8, 3. doi: 10.35691/JBM.1202.0198

Ayeni, L. S., and Ezeh, O. S. (2017). Comparative Effect of NPK 20:10:10, organic and organo-mineral fertilizers on soil chemical properties, nutrient uptake and yield of tomato (Lycopersicon esculentum). Appl. Tropic. Agricult. 22, 111-116. doi: 10.13140/RG.2.2.18726.63049

Bashir, S., Bashir, S., Bakhsh Gulshan, A., Jamal Khan, M., Iqbal, J., Sherani, J., et al. (2021). The role of different organic amendments to improve maize growth in wastewater irrigated soil. J. King Saud Univ. Sci. 33:10518.

Bergstrand, K.-J., Löfkvist, K., and Asp, H. (2020). Dynamics of nutrient availability in tomato production with organic fertiliser. Biol. Agricult. Horticult. 36, 200-212. doi: 10.1080/01448765.2020.1779816

Blanco-Canqui, H. (2017). Biochar and soil physical properties. Soil Sci. Soc. Am. J. 81, 687. doi: 10.2136/sssaj2017.01.0017

Bray, R. H., and Kurtz, L. T. (1945). Determination of total organic and available forms of phosphorus in soils. Soil Sci. 59, 39-45. doi: 10.1097/00010694-194501000-00006

CILSS (2017). Flux transfrontaliers de produits agricoles et d'élevage au Sahel et en Afrique de l'Ouest. Programme régional d'appui accès aux marchés, Comité Permanent Inter-Etats de Lutte contre la Sécheresse dans le Sahel, p. 9.

Fairhurst, T. (2012). Handbook for integrated soil fertility management. Africa soil health consortium, Nairobi. ISBN: $9781780642918,154$.

Faostat (2020). Production de la tomate dans le monde, en Afrique et au Burkina Faso. Available online at : http://www.fao.org/faostat/fr/\#data/QC (accseesd 25/06/2020).

Fernandes, P., and Bhalerao, S. A. (2015). Effect of biofertilizer on the growth and biochemical parameters of Mungbean Vigna radiate (L, Wilczek). Int. J. Adv. Res. Biol. Sci. 2, 127-130. Available online at: http://ijarbs.com/pdfcopy/ apr2015/ijarbs17

Ferrante, A., and Mariani, L. (2018). Agronomic management for enhancing plant tolerance to abiotic stresses: high and low values of temperature, light intensity, and relative humidity. Horticulturae 4, 21.

Fidel, R. B., Laird, D. A., and Spokas, K. A. (2018). Sorption of ammonium and nitrate to biochars is electrostatic and pHdependent. Scientific Rep. 8, 17-27. doi: 10.3390/horticulturae4030021

Glaser, B., Lehmann, J., and Zech, W. (2002). Ameliorating physical and chemical properties of highly weathered soils in the tropics with charcoal-a review. Biol. Fertil. Soils 35, 219-230. doi: 10.1007/s00374-002-0466-4

Gorovtsov, A. V., Minkina, T. M., Mandzhieva, S. S., Perelomov, L. V., Soja, G., Zamulina, I.V., et al. (2019). The mechanisms of biochar interactions application of organic amendments and mineral fertilizers had more advantages than the application of organic amendment alone. The combined application of neem seed cake and mineral fertilizers was more effective on tomato productivity in this study.

\section{DATA AVAILABILITY STATEMENT}

The raw data supporting the conclusions of this article will be made available by the authors, without undue reservation.

\section{AUTHOR CONTRIBUTIONS}

All authors listed have made a substantial, direct, and intellectual contribution to the work and approved it for publication. with microorganisms in soil. Environ. Geochemistr. Health. 42, 2495-2518; doi: 10.1007/s10653-019-00412-5

Hamer, U., Marschner, B., Brodowski, S., and Amelung, W. (2004). Interactive priming of black carbon and glucose mineralization. Organic Geochemistr. 35, 823-830. doi: 10.1016/j.orggeochem.2004. 03.003

Islam, A., Islam, S., Akter, A., Rahman, M.,d,. H., and Nandwani D (2017). Effect of Organic and inorganic fertilizers on soil properties and the growth, yield and quality of tomato in mymensingh, Bangladesh M. Agriculture 7, 18. doi: 10.3390/agriculture7030018

Koul, O., and Shankar, J. S. (1995). Systemic uptake of azadirachtin into Ricinus communis and its effects on Spodoptera litura larvae. Indian J. Experiment. Biol. 33, 865-867.

Lehmann, J., Gaunt, J., and Rondon, M. (2006). Bio-char sequestration in terrestrial ecosystems-a review mitigation and adaptation strategies for global. Change 11, 403-427. doi: 10.1007/s11027-005-9006-5

MAAHA (2019). Rapport de l'Enquête maraichère 2018, 28p.

MAHRH (2011). Rapport d'analyse du module maraîchage. Rapport d'étude phase 2: RGA 2006-2010, Ministère de l'Agriculture de l'Hydraulique et des Ressources Halieutiques, Ouagadougou, Burkina Faso 214p.

Metson, A. J. (1956). Methods of chemical analysis for soil survey samples. NZ Soil Bur Bull $n^{\circ} 12$

Mitran, T., Mani, P. K., Bandyopadhyay, P. K., and Basak, N. (2017). Influence of organic amendments on soil physical attributes and aggregate associated phosphorus under long-term rice wheat-cropping. J. King Saud Univ. Sci. 33, 101583. doi: 10.1016/S1002-0160(17)60423-5

Mulugeta, A., Getahun, B. (2020). Effects of organic amendments on soil fertility and environmental quality: a review. J. Plant Sci. 8, 112-119. doi: $10.11648 /$ j.jps.20200805.12

Mustafa, K. H., r., Strezov, V., Chan, K. Y., and Nelson, P. F. (2010). Agronomic properties of wastewater sludge biochar and bioavailability of metals in production of cherry tomato (Lycopersicon esculentum). Chemosphere 78, 1167-1171. doi: 10.1016/j.chemosphere.2010.01.009

Nguyen, T. T. N., Wallace, H. M., Xu, C. Y., Xu, Z., Farrar, M. B., Joseph, S., et al. (2017). Short-term effects of organo-mineral biochar and organic fertilizers on nitrogen cycling, plant photosynthesis, and nitrogen use efficiency. J. Soils Sediment. 17, 2763-2774. doi: 10.1007/s11368-0171839-5

Oyinlola, E. Y., Paul, O. O., and Uyovbisere, E. O. (2017). Effect of neem seed cake and inorganic fertilizer on yield of tomato and soil properties in northern guinea savanna of Nigeria. Euro. J. Agricult. Forestr. Res. 5, 1-15.

PNDES (2016). Plan National de Développement Economique et Social du Burkina Faso (2016-2020), p. 87.

Puri, H. S. (1999). NEEM: the Divine Tree Azadirachta indica. Melbourne: Harwood Academic Publishers.

Ramzan, S., Ashraf, F., Ali, T., Rasool, T., Ahmad, P., Wani, M. A., et al (2021). "Responses of soil properties to organic amendments," in Microbiota 
and Biofertilizers, eds Hakeem K.R., Dar G.H., Mehmood M.A., Bhat R.A. (Cham: Springer).

Toor, R. K., Savage, G. P., and Heeb, A. (2006). Influence of different types of fer-tilizers on the major antioxidant components of tomatoes. J. Food Composit. Anal. 19, 20-27. doi: 10.1016/j.jfca.2005. 03.003

Ullah, I., Mao, H., Rasool, G., Gao, H., Javed, Q., Sarwar, A., et al. (2021). Effect of deficit irrigation and reduced $\mathrm{n}$ fertilization on plant growth, root morphology and water use efficiency of tomato grown in soilless culture. Agronomy 11, 228. doi: 10.3390/agronomy11020228

Van Zwieten, L., Kimber, S., Morris, S., Chan, K. Y., Downie, A., Rust, J., et al. (2009). Effect of biochar from slow pyrolysis of papermill waste on agronomic performance and soil fertility. Plant Soil. 9, 50. doi: 10.1007/s11104-0090050-x

Walkley, A. J., and Black, I. A. (1934). Estimation of soil organic carbon by the chromic acid titration method. Soil Sci. 37, 29-38. doi: 10.1097/00010694-193401000-00003

Wu, Y., Yan, S., Fan, J., Zhang, F., Zheng, J., Guo, J., et al. (2020). Combined application of soluble organic and chemical fertilizers in drip fertigation improves nitrogen use efficiency and enhances tomato yield and quality. J. Sci. Food Agricult. 100, 5422-5433. doi: 10.1002/jsfa. 10593
Youssef, M. A., and Eissa, M. A. (2017). Comparison between organic and inorganic nutrition for tomato. J. Plant Nutri. 40, 1900-1907. doi: $10.1080 / 01904167.2016 .1270309$

Conflict of Interest: The authors declare that the research was conducted in the absence of any commercial or financial relationships that could be construed as a potential conflict of interest.

Publisher's Note: All claims expressed in this article are solely those of the authors and do not necessarily represent those of their affiliated organizations, or those of the publisher, the editors and the reviewers. Any product that may be evaluated in this article, or claim that may be made by its manufacturer, is not guaranteed or endorsed by the publisher.

Copyright (c) 2022 Traoré, Bandaogo, Savadogo, Saba, Ouédraogo, Sako, Sermé and Ouédraogo. This is an open-access article distributed under the terms of the Creative Commons Attribution License (CC BY). The use, distribution or reproduction in other forums is permitted, provided the original author(s) and the copyright owner(s) are credited and that the original publication in this journal is cited, in accordance with accepted academic practice. No use, distribution or reproduction is permitted which does not comply with these terms. 